\title{
WADAH KERJA MILENIAL DAN BALAI BOGA
}

\author{
Andy Lois ${ }^{1)}$ \\ 1) Program Studi S1 Arsitektur, Fakultas Teknik, Universitas Tarumanagara, louis.andylois@gmail.com
}

\begin{abstract}
Abstrak
Ruang Kerja Bersama dan Balai Boga di Jakarta merupakan fasilitas yang didesain didasari oleh kebutuhan serta perkembangan bisnis ekonomi kreatif yang kian pesat namun belum ada fasilitas yang memadai dan mendukungnya saat ini. Sehingga masalah desain utama adalah bagaimana menciptakan ruang yang dapat menyampaikan identitas dan menjadi ikon perkembangan ekonomi kreatif di Jakarta. Selain itu adanya kebutuhan para pengembang bisnis untuk bekerja secara produktif, maka proyek ini juga mengangkat masalah desain khusus yaitu bagaimana menciptakan ruang sosial dan ruang hijau untuk mendukung produktivitas lebih dari user. Pendekatan desain yang digunakan adalah pendekatan umum dan pendekatan simbolik dengan menggunakan intangible metaphore, mengambil dari sifat utama para pengembang bisnis pemula yakni Inovasi. Kemudian, pendalaman karakter ruang dipilih untuk mencermati penyelesaian kebutuhan ruang-ruang kerja yang berbeda sesuai dengan kebutuhan pengguna. Fasilitas ini berbeda dengan ruang kerja pada umumnya karena mengutamakan ruang interaksi (interaction space) dan juga ruang hijau, namun tidak mengabaikan privasi yang dibutuhkan setiap pengguna. Desain kantor dan ruang kerja bersama juga didukung dengan fasilitas seperti cafetaria, ruang berkumpul, ruang rapat, dan juga retail.
\end{abstract}

Kata Kunci : balai boga; ruang interaksi; ruang kerja bersama

\begin{abstract}
The Co-working space and Food Hall in jakarta is a facility that designed based on the needs and development of creative economy business that growing rapidly but there are no adequate facilities and support at this time. So the main design problem is how to create space that can convey identity and become an icon of the development of creative economy in Jakarta. Besides the needs for business developers to work productively, this project also raises special design issues, namely how to create social space and green space to support more productivity of users. The design approach used is a general approach and a symbolyc approach using intangible metaphor, taking from the main nature of business startup developers namely innovation. Then, the deepening of space characters is chosen to look at the completion of the needs from different workspaces according to users needs. This facility is different from the workspace in general because it prioritizes intercation space (interaction sapce) and also green space, but does not ignore the privacy needed by each user. Office and Co-working space designs are also supported by facilities such as cafetaria, gathering room, meeting room, and retail.
\end{abstract}

Keywords : co-working space; food hall; interaction space

\section{PENDAHULUAN}

Ada beberapa masalah utama yang disoroti dari generasi millennial dan kedua hal ini membuat banyak anggapan bahwa generasi millennial merupakan generasi yang malas dan memiliki semangat rendah dan tidak produktif, padahal akar dari masalah-masalah tersebut adalah:

\section{-Impatience / tidak sabar}

Ketidaksabaran atas pekerjaan yang dimiliki merupakan masalah yang terjadi pada generasi ini, menyebabkan banyak generasi millennial mudah dan cepat untuk keluar dari suatu 
perusahaan, dan hanya bertahan kurang dari delapan bulan. Ini karena millennial tidak puas karena mereka merasa tidak membuat suatu "impact" yang berarti pada perusahaan, maupun tidak adanya kemajuan dari sesuatu yang mereka telah kerjakan. Generasi ini tidak melihat suatu "rintangan" yang perlu terlebih dahulu harus dilalui, mereka hanya tertuju kepada goal yang mereka inginkan.

Kesabaran akan terbentuk dari sikap toleransi yang akan terbentuk seiring dengan berjalannya waktu dan proses Panjang. Proses ini akan lebih baik ketika seorang individu lebih sering bersosialisasi dan bertukar pendapat yang akan membuat perasaan lebih tenang karena dalam prosesnya akan terjadi saling dukung dan pertukaran ilmu.

\section{-Environment / lingkungan}

Lingkungan kerja yang tercipta saat ini lebih cenderung mementingkan kuantitas, yang menyebabkan pekerja melakukan sesuatu tidak dengan tanggung jawab. Dan mereka berada di lingkungan perusahaan yang tidak membantu mereka dalam mengembangkan rasa percaya diri mereka, serta tidak skill kerja sama yang membentuk empati, sehingga terbentuk budaya kerja yang tidak menghiraukan sesame maupun rekan kerjanya, yang tanpa disadari akan membuat suatu tim kerja lebih sulit mencapai "Goals" secara maksimal.

Social Skills akan sangat membantu dalam pemecahan masalah-masalah yang dihadapi, salah satunya dengan lingkungan kerja yang dibentuk diantara berbagai komunitas yang berbeda latar belakang maupun bidang dan memungkinkan terjadinya pertukaran ide dan sosialisasi. Selain itu perlu adanya bantuan teknologi yang membuat startup dan entrepreneur yang sedang berkembang dapat berfikir dan memiliki ide yang luas

Masalah-masalah ini juga sering dijadikan bahan penelitian oleh beberapa perusahaan, seperti sebuah penelitian dari Price Water House Coopers (PWC) tentang kecenderungan generasi millennial untuk bekerja dan memulai suatu usaha mandiri

\section{Millennials \& Entrepreneurship}

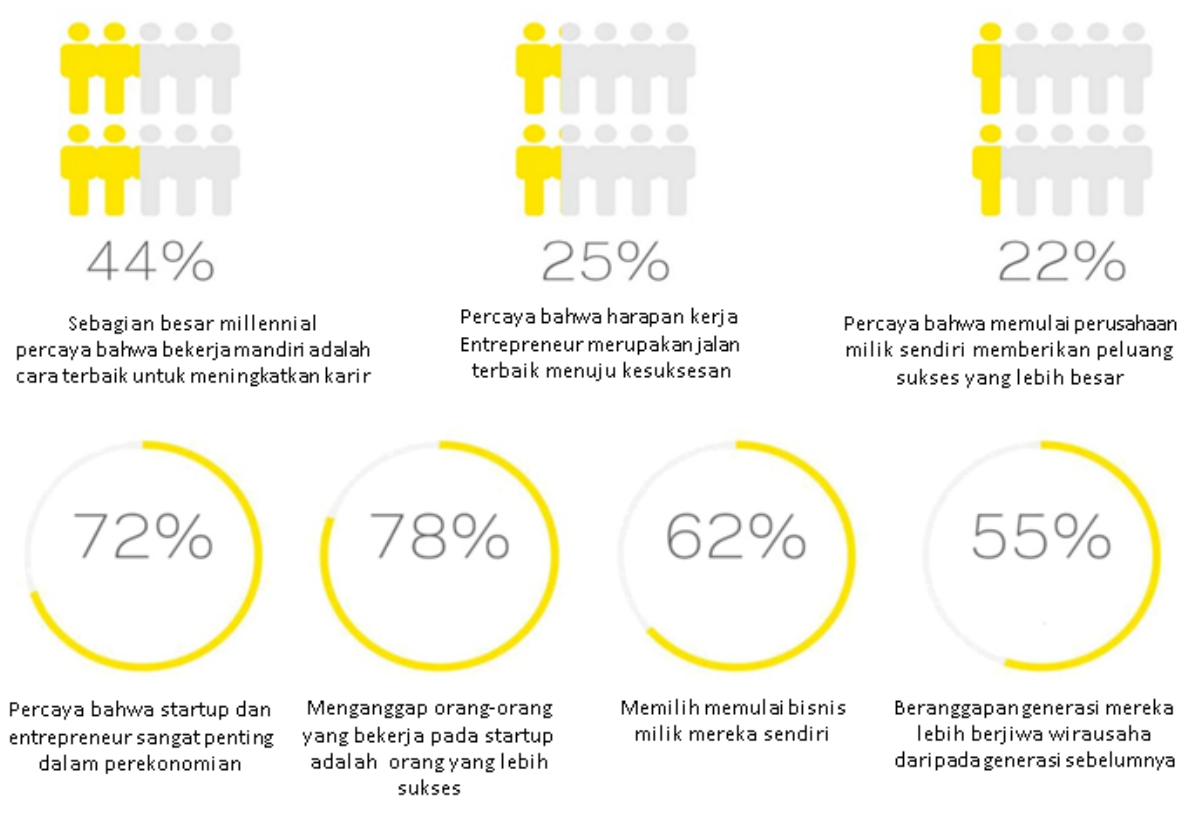

Gambar 1. Kecenderungan Millenial Terhadap Startup

Sumber : www.pwc.co.uk 
Millenial sangat optimistis dengan startup dan entrepreneur sebagai pilihan karir yang baik karena kebebasan dan kemungkinan untuk mengembangkan diri sangat terbuka lebar.

Alasan generasi millennial lebih memilih startup adalah:

\section{a. Bebas Berekspresi}

Mayoritas orang suka kebebasan berekspresi, hampir semua orang merasa perlu untuk melepaskan ekspresi mereka dalam setiap aspek kehidupan. Termasuk saat bekerja, di dalam perusahaan startup, sangat mudah untuk bebas berekspresi ketika bekerja karena lingkungan yang dipenuhi para millennial yang sangat terbuka dan menerima perbedaan pendapat hampir di setiap saat.

\section{b. Bebas mengeluarkan ide kreatif}

Para millennial umumnya mempunyai ide segar dan "gila" yang terkesan tidak mungkin untuk diterapkan dalam perusahaan dengan kebijakan konvensional. Dalam perusahaan startup justru ide-ide seperti itulah yang dibutuhkan.

\section{c. Atmosfer kerja yang menyenangkan}

Rekan kerja yang mayoritas berusia sama dan sebaya, secara otomatis menjadikan perusahaan startup memliki atmosfer kerja yang menyenangkan. Ditambah lagi dengan desain interior kantor yang seringnya didesain kreatif yang membuat tidak mudah bosan.

\section{d. Selalu terhubung dengan media sosial}

Poin yang satu ini nampaknya adalah bukan hanya alasan millennial memilih perusahaan startup sebagai tempat bekerja, tapi juga merupakan alasan mengapa perusahaan startup memilih millenial untuk menjadi bagian dari tim. Tuntutan untuk selalu berkembang dan update dengan berita terbaru memang mengharuskan seseorang untuk selalu terhubung dengan media sosial. Selain itu, millennial tidak perlu khawatir untuk terus mengecek media sosial di jam kerja, karena memang itulah inti dari pekerjaan mereka di perusahaan startup.

e. Banyak kesempatan belajar membangun bisnis

Poin penting yang menjadi alasan millennial memilih perusahaan startup sebagai tempat membangun karir adalah pengalaman yang didapatkan. Bekerja di perusahaan startup secara tidak langsung mengajarkan kita untuk membangun atau merintis bisnis dari awal.

Seperti kita ketahui, ketika bekerja di perusahaan startup, kita dapat dengan mudah bertukar pikiran dan belajar langsung dengan atasan. Ditambah lagi, sistem bekerja learning by doing yang menjadi pengalaman berharga yang tak tergantikan merupakan nilai tambah yang banyak dicari.

Kesimpulannya adalah bahwa masyarakat Urban Middle-Class Millennial (Millenial Muda) memiliki tiga karakter utama, yaitu 3C: connected, creative, dan confidence. Pertama, connected. Generasi millennial adalah pribadi yang pandai bersosialisasi, terutama dalam komunitas yang mereka ikuti serta berkelana di media sosial. Kedua, creative. Mereka adalah orang yang biasa berpikir out of the box, kaya akan ide dan gagasan serta mampu mengomunikasikan ide secara dengan baik yang dibuktikan dengan tumbuhnya industri yang dimotori oleh anak muda. Ketiga, confidence. Mereka merupakan orang yang percaya diri, berani mengungkapkan pendapat, serta tidak sungkan berdebat di depan public 


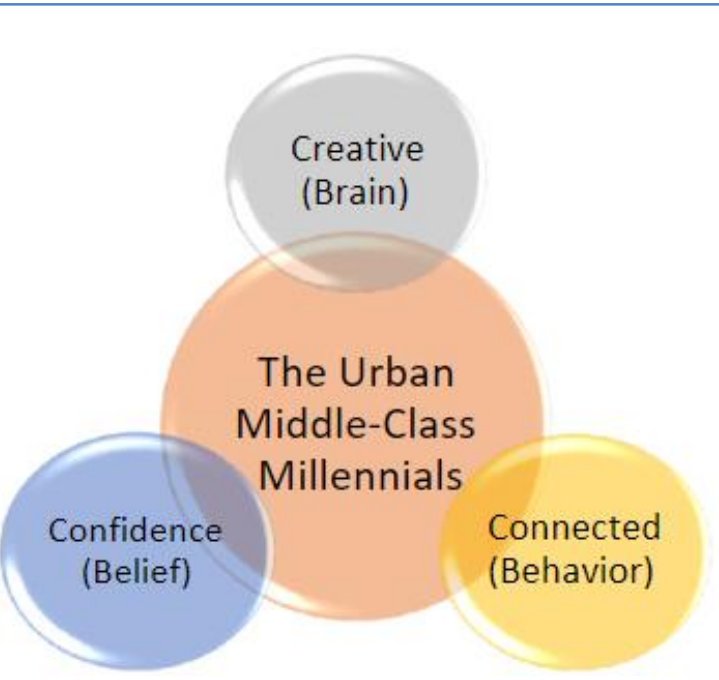

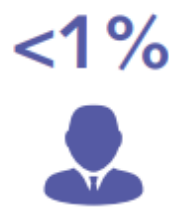

BABY BOOMERS

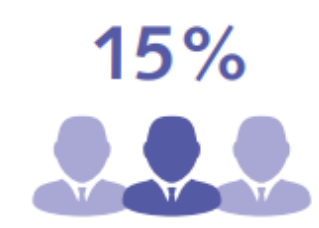

GENERATION X

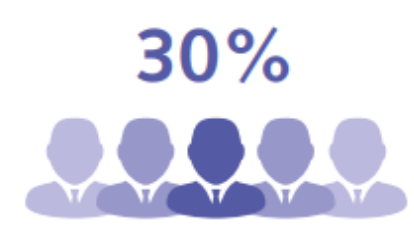

MILLENNIALS

Gambar 2. Dominasi Pilihan Millenial

Kebanyakan dari millennial memilih bekerja pada lingkungan yang fleksibel dan tidak terkesan formal dimana pada lingkungan kerja demikian pekerja dapat dengan nyaman mengemukaan pendapat dan ide. Hal inilah yang menyebabkan startup menjadi pilihan kaum millennial.

\section{KAJIAN LITERATUR}

\section{Generasi Millennial}

Generasi Millennial adalah terminologi generasi yang saat ini banyak diperbincangkan oleh banyak kalangan di dunia diberbagai bidang, Millennials (juga dikenal sebagai Generasi Millenial atau Generasi Y) adalah kelompok demografis (cohort) setelah Generasi X.

Rentang kelahiran generasi Millenial menurut beberapa ahli adalah:

- Howe dan Strauss mendefinisikan kelompok milenial sebagai terdiri dari individu yang lahir antara tahun $1982-2004$.

- Menurut Iconoclast, sebuah perusahaan riset konsumen, generasi milenial pertama lahir pada 1978.

- Majalah Newsweek melaporkan bahwa generasi milenial lahir antara 1977 - 1994.

- Dalam artikel terpisah, New York Times mematok generasi milenial pada 1976-1990 dan $1978-1998$.

- Artikel majalah Time menempatkan generasi millenial pada kelahiran antara 1980 - 2000.

(www.whatis.techtarget.com).

Secara garis besar, rentang kelahiran untuk Generasi Milenial dari berbagai sumber adalah 1976 dan yang terakhir tahun 2004. Yang berarti generasi millennial merupakan orang-orang dengan rentang umur 18 hingga 38 tahun. Di Indonesia sendiri generasi millennial akan menjadi angkatan kerja terbesar di Indonesia. Berdasarkan data BPS di tahun 2016, dari total jumlah angkatan kerja di Indonesia yang mencapai 160 juta, hampir 40\% di antaranya tergolong millennial sebesar 62,5 juta. Terbanyak kedua setelah generasi $X$ yang mencapai 69 juta, dan jauh di atas generasi Baby Boomers yang hanya sekitar 28,7 juta. 


\section{Co-Working Space}

Berdasarkan dari kamus Oxford, co-working space merupakan lingkungan kerja atau kantor yang digunakan oleh orang-orang yang bekerja sendiri atau bekerja untuk perusahaan yang berbeda-beda. Secara khusus co-working space menawarkan lingkungan kerja yang saling berbagi peralatan, ide dan pengetahuan.

Selain itu, pengetian lainnya yaitu co-working space meliputi penyewaan ruang kerja yang digunakan secara bersama-sama dan terbuka dengan pengguna lainnya dengan penggunaan waktu yang fleksibel. Ruang kerja pada co-working space digunakan oleh orang-orang dengan latar yang berbeda-beda antara lain yaitu, enterpreneur, freelancer, startup, asosiasi, konsultan, investor, peneliti, pelajar dll (Leforestier, 2009, hal. 3).

Dengan berbagai latar belakang pengguna pada co-working space, para coworkers (istilah untuk pengguna co-working space) dapat saling berinteraksi dan menawarkan keahliannya masing-masing untuk sebuah proyek sehingga terjadilah sebuah kolaborasi. Co-working space didasarkan pada nilai-nilai penting yaitu partisipasi, berbagai pikiran yang terbuka.

Co-working space pada dasarnya didedikasikan untuk para pengusaha yang merasa sendiri dalam menjalankan usaha, khawatir dengan perasaan terisolasi, kehilangan interaksi antar manusia dan mencoba mencari peluang dari bersosialisasi. Melalui co-working space para pengusaha dapat berbagi pengalamannya mereka (Leforestier, 2009, hal. 4)

\section{Startup}

Istilah startup sering kali dihubung-hubungkan dengan perusahaan baru di bidang teknologi dan informasi karena istilah "startup" menjadi populer secara internasional pada masa bubble dot-com (tahun 1998 hingga 2000), karena banyak perusahaan berbasis internet yang didirikan secara bersamaan pada periode tersebut.

Dengan demikian, banyak perusahaan yang memanfaatkan internet sebagai sarana mengembangkan bisnisnya hingga lahirlah bisnis startup.

Karakteristik dari startup antara lain adalah sebagai berikut:

- Usia perusahaan kurang dari 3 tahun,

- Jumlah pegawai kurang dari 20 orang,

- Masih dalam tahap berkembang,

- Umumnya beroperasi dalam bidang teknologi,

- Produk yang dibuat berupa aplikasi dalam bentuk digital,

- Biasanya beroperasi melalui website.

- Lingkungan kerja yang fleksibel menjadi pilihan.

\section{Perkembangan Bisnis Startup Di Indonesia}

Untuk di Indonesia sendiri perkembangan startup cukup bagus. Setiap tahun banyak founder-founder (pemilik) Startup baru bermunculan di indonesia. Menurut Badan Riset Nasional sekarang ini terdapat setidaknya lebih dari 1500 Startup lokal yang ada di Indonesia. Potensi pengguna internet Indonesia yang semakin naik dari tahun ke tahun yang tentunya memberikan prospek baik untuk mendirikan sebuah Startup.

Startup di Indonesia digolongkan dalam tiga kelompok yaitu Startup pencipta game, Startup aplikasi edukasi serta Startup perdagangan seperti e-commerce dan informasi, startup game dan aplikasi edukasi punya pasar yang potensial dan terbuka di Indonesia. Hal ini dikarenakan proses pembuatan game dan aplikasi edukasi relatif mudah. 


\section{METODE}

\section{METODE PERANCANGAN}

\section{Studi Pustaka}

1. Karakteristik dan fungsi umum co-working space dan creative space

2. Standar ruang co-working space

3. Studi preseden tema terkait

4. Peraturan-peraturan pemerintah setempat

\section{Studi Banding dan Studi Kasus}

Melakukan kunjungan dan analisis terhadap bangunan dengan tipologi yang serupa dan selanjutnya melakukan komparasi sebagai dasar referensi dalam proses perancangan

\section{Studi Lapangan}

Melakukan kegiatan survey lapangan berupa gambar, foto, beberapa data statistik tematik, dan menganalisis terhadap lokasi terkait untuk mengetahui kondisi fisik maupun sosial yang ada pada lokasi.

\section{Seleksi Kembali}

Melakukan penyeleksian kembali informasi yang telah didapatkan baik secara arsitektural maupun aspek non-arsitektural untuk kemudian diolah mkembali menjadi sebuah gagasan yang baik.

\section{DISKUSI DAN HASIL}

Secara umum metode yang digunakan dalam proses perancangan di projek ini merujuk pada proses perancangan lima langkah (Tim Mc.Ginty) dalam buku "Pengantar Arsitektur" oleh James C. Snyder dan Anthony J. Catanese (1984). Proses tersebut terdiri dari permulaan, persiapan, pembuatan usulan, evaluasi, dan tindakan. Kelima tahapan tersebut antara lain:

1) Tahap Permulaan

Tahap permulaan, merupakan proses penjabaran permasalahan yang harus dipecahkan dari perencanaan fasilitas co-working Space di kawasan Setiabudi. Pada perencanaan, proses ini terdapat pada Bab I yang terdiri dari latar belakang, rumusan masalah, dan tujuan. Proses awal ini bertujuan untuk mengetahui sampai dimana permasalahan pada rancangan yang akan dipecahkan, dari segi fisik dan non fisik, secara teknis maupun non teknis. Proses awal ini akan menentukan informasi mengenai apa saja yang harus dikumpulkan

\section{2) Tahap Persiapan}

Tahap persiapan, yaitu tahap pengumpulan dan analisis informasi atau data mengenai permasalahan yang harus dipecahkan. Pada perancangan fasilitas co-working Space tahapan ini terdapat pada Bab II yaitu, pemahaman secara teori terhadap co-working Space dan hal-hal pendukungnya, studi preseden proyek sejenis maupun proyek yang memiliki tipe yang sama dengan proyek. Adapun fasilitas sejenis yang dipergunakan adalah Fosbury \& Sons CoWorking, Simplywork 3.0 Co-Working, Simplywork 6.0 Co-Working, Zhongshan Road CoWorking, dan Publik Office In Saigon. Data lainnya seperti pemahaman fasilitas co-working Space serta pemahaman tentang permasalahan millennial yang diangkat, didapatkan melalui jurnal dan buku terkait.

3) Tahap Pembuatan Usulan

Tahap pembuatan usulan, yaitu tahapan pengajuan usulan terhadap permasalahan yang dirumuskan berdasarkan informasi dan hasil analisis. Pada perancangan co-working Space, tahapan tersebut ada pada Bab IV dan Bab V, yaitu pada program-program, serta data-data tapak yang dibutuhkan dalam perancangan. Konsep yang dihasilkan kemudian ditransformasikan saat studio tugas akhir dalam bentuk gambar kerja.

\section{4) Tahap Evaluasi}

Tahap evaluasi adalah tahapan penilaian terhadap usulan-usulan yang telah dihasilkan. Tahapan evaluasi sudah mulai diolah dan pengevaluasian alternatif-alternatif program maupun konsep pada Bab IV. 


\section{5) Tahap Tindakan}

Tahap tindakan adalah tahapan desain atau pra-rancangan dan detail ruangan. Tahapan ini akan dimulai pada saat memasuki studio tugas akhir dalam penggambaran detail dan gambar kerja.

Dari isu millennial yang dibahas dan berdasarkan literatur, program utama pada proyek ini adalah penyediaan space kerja bagi generasi millenial.

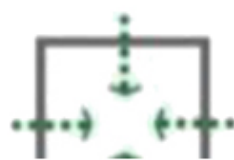

Centris, Masif, Intensitas Tinggi

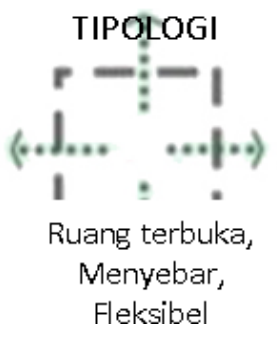

Gambar 3. Tipologi

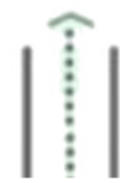

Organik, Intensitas rendah, Linear

Pendekatan umum berupa pengamatan sekitar dan pendekatan simbolik dengan menggunakan intangible metaphore, mengambil dari sifat utama para pengembang bisnis start-up yakni Inovasi.
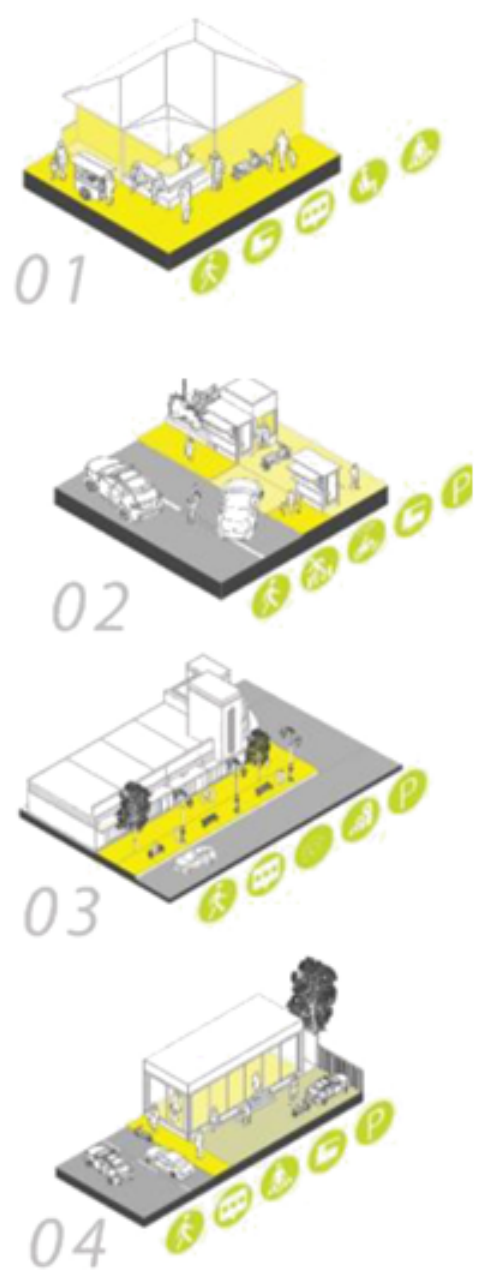

"Berbagai macam interaksi terjadi di dalam gang dikarenakan adanyaketerbatasan ruang berkegiatan bagi masyarakat sekitar. Ruangyang terdefinisi padasite adal ah sebagai tempat untuk berbagai macam kegiatan umum"

"Muncul kegiatan nonformal karena kurangnya fasilitas terutama penjual makananyang memenuhi gang dan sebagian menyebar disekitartapak"

"Daya tarik kawasan ini adalah pedestrian disekitaryang nyaman sertavegetasi sebagai naunganyang cukup banyak di sepanjangjalan, namun kurang didukung oleh fasilitas parkiryang rapi dan aman"

\footnotetext{
"Kurangnya fasilitas parkir di sekitar site mengakibatkan penggunaan bahujal an serta penggunaan lahan kosong di sekitar sebagai area parkirliar"
}

Gambar 4. Pendekatan Rancangan 
Dengan tahapan selanjutnya adalah pengolahan gubahan massa

DESIGN SCHEME

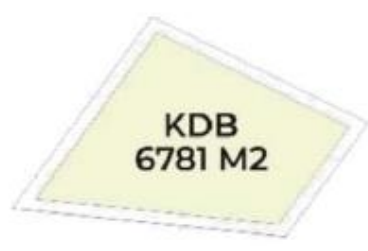
Luasan tapak yang
diolah

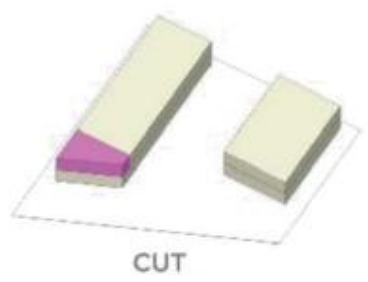

Pengurangan massa agar massa tidak terlalu masif

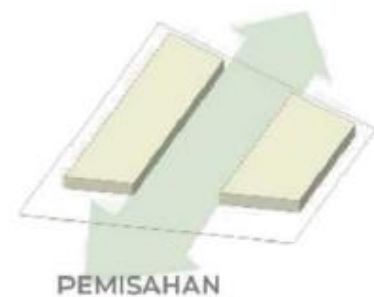

Massa dibagi menjadi dua berdasarkan axis utama

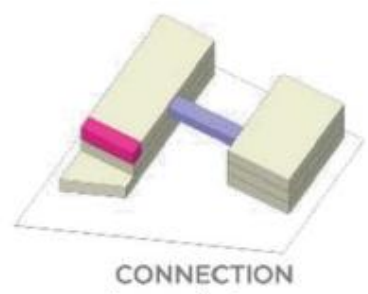

Penyambungan kedua massa dengan jembatan

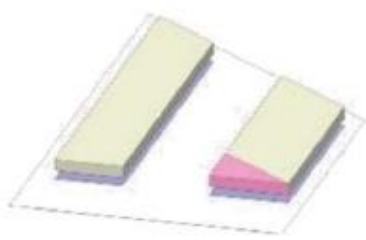

PENGANGKATAN

Massa diangkat sehingga membentuk ruang lebih tinggi dibagian bawah

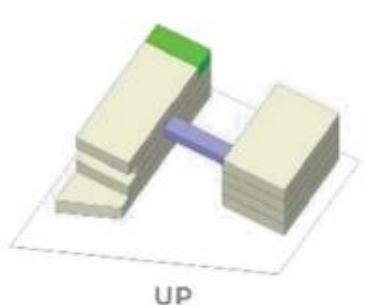

Massa dinaikkan dan dipotong Untuk membentuk ruang hijau Dibagian atas

Gambar 5. Design Schemes

Dengan penggambaran visual secara prespektif
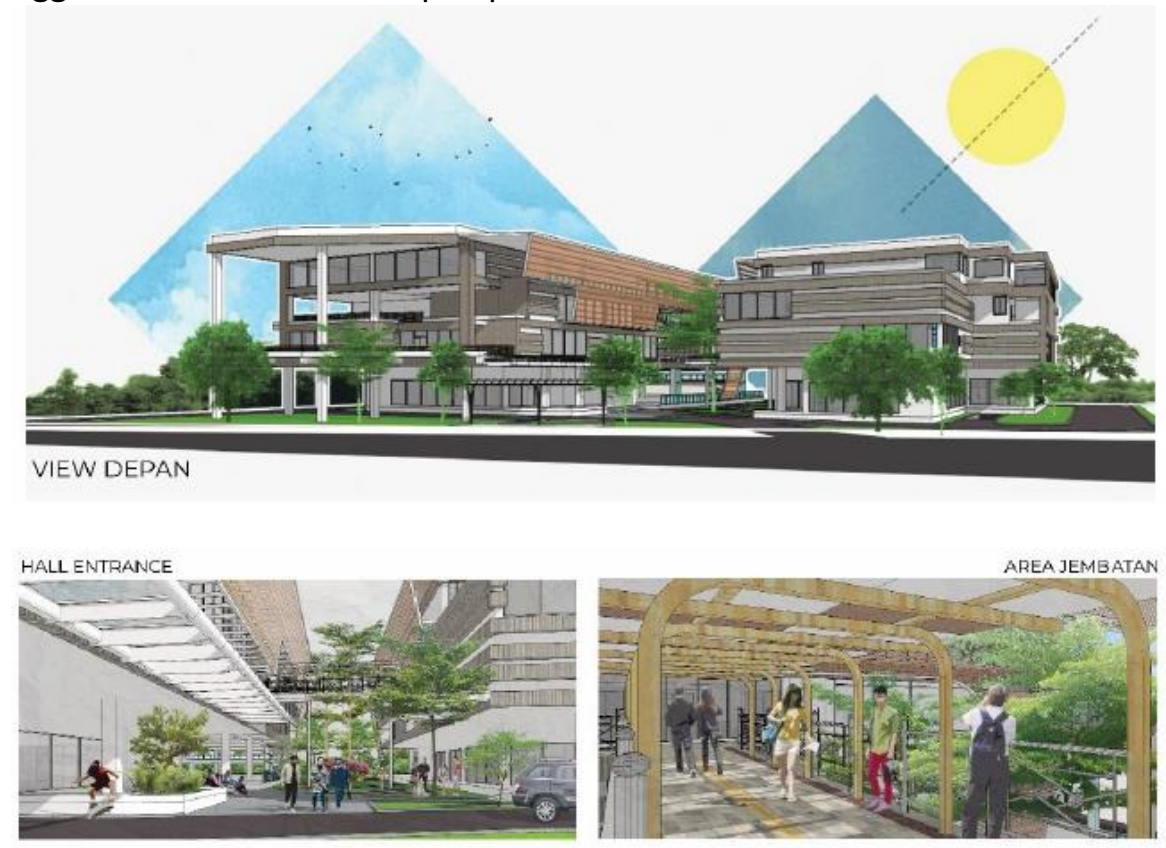

Gambar 6. Penggambaran secara prespektif 

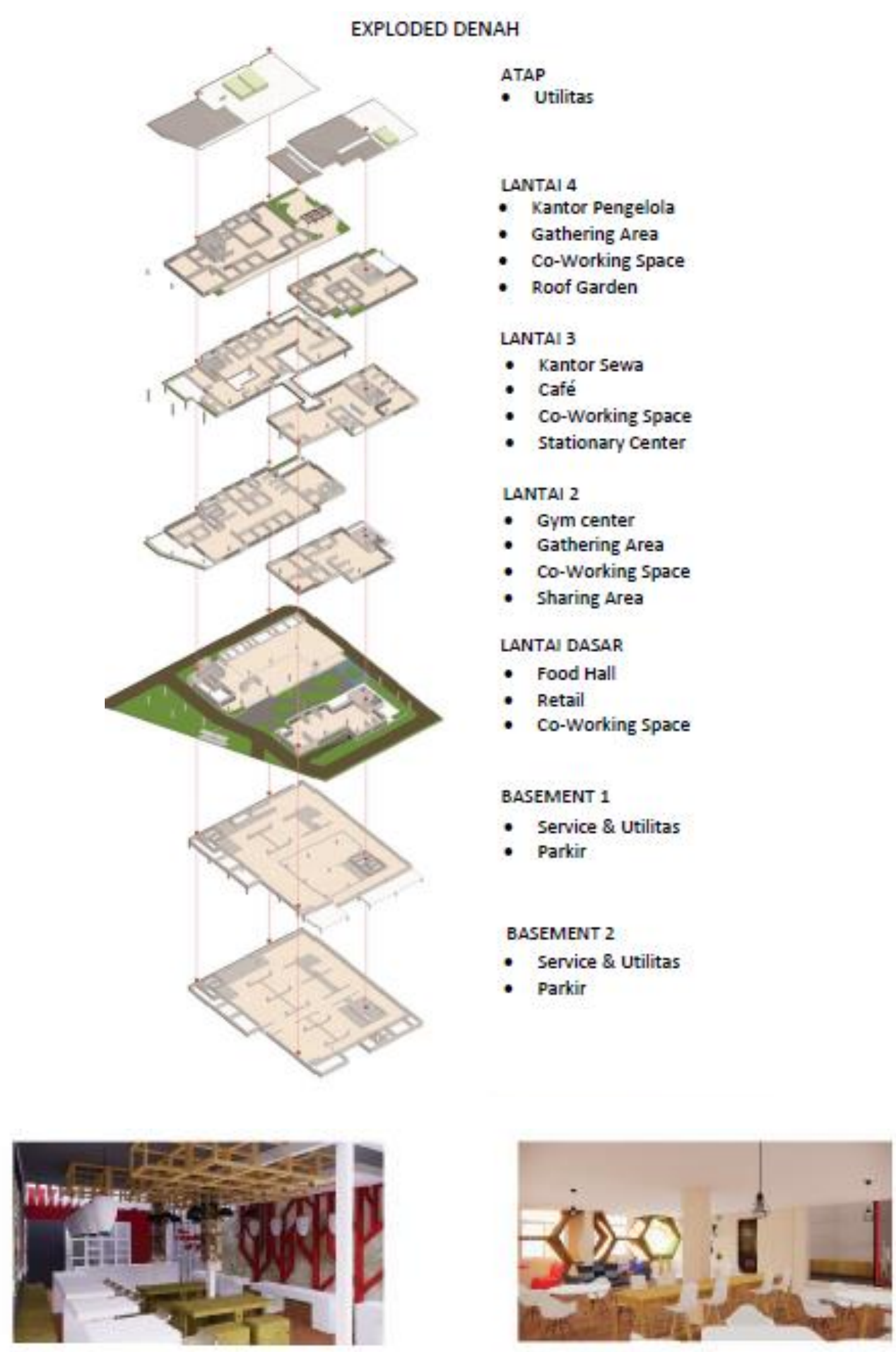

Cafe

Cow Working Spsce

Gambar 6. Exploded denah 


\section{KESIMPULAN DAN SARAN \\ Kesimpulan}

Kota Jakarta merupakan kota maju dan padat penduduk,yang menyebabkan mahalnya lahan dan berdampak pada orang-orang yang ingin memulai bisnis, atau bekerja bersama, tetapi dengan modal yang terbatas. Konsep Co-Working space merupakan solusi dari permasalahan tersebut karena memanfaatkan ruang bekerja bersama (Sharing Space) yang dilengkapi dengan banyak fasilitas pendukung, dan pengguna dapat menjalin interaksi sesama pengguna yang memberikan keuntungan jaringan relasi. Dalam perancangan suatu CoWorking Space sendiri, memerlukan adanya inovasi suatu ruang agar ruangan tersebut memiliki keunggulan, keunikan, dan identitas yang berbeda dengan fasilitas sejenis. Konsep Fresh, Smart, dan Flexible adalah tiga konsep yang akan diangkat pada proyek ini dimana konsep Fresh diaplikasikan pada ruangan dalam bentuk material dan warna yang digunakan selain itu area hijau akan dimasukkan ke dalam ruangan dalam bentuk bukaan dan taman yang akan memberikan udara segar, sedangkan konsep smart diterapkan kedalam sistem dan elemen interior, yang terakhir adalah konsep Flexible yang memungkinkan setiap ruang dapat menyesuaikan fungsi sesuai kebutuhan, tujuannya adalah peningkatan produktifitas dan efisiensi dalam penggunaan waktu, biaya, dan tenaga

\section{Saran}

Perancangan proyek ini masih memerlukan adanya kelanjutan dalam studi dan analisis guna untuk melengkapi dan mengembangkan desain yang telah dirancang.

\section{DAFTAR PUSTAKA}

Ali, H. (n.d.). Generasi Millennial Indonesia: Tantangan dan Peluang Pemuda Indonesia. Retrieved from alvara-strategic.com: http://alvara-strategic.com/generasi-millennialindonesia-tantangan-dan-peluang-pemuda-indonesia/

Asghar, R. (2014, November 11). Study: Millennials Are The True Entrepreneur Generation. Retrieved from forbes.com: https://www.forbes.com/sites/robasghar/2014/11/11/studymillennials-are-the-true-entrepreneur-generation/\#69ae4a3f73dc

Burgett, B. (2018, Agustus 20). The most millennial spending habits. Retrieved from havenlife.com: https://havenlife.com/blog/millennial-spending-habits/

Bilson, S. (2004). Panduan Riset Perilaku Konsumen. Jakarta : Gramedia.

Ching, F. D. (2000). Arsitektur, Bentuk, Ruang, dan Susunannya. Jakarta: Erlangga.

Daniel W. P. (2016). "The Missing Millennial Entreprenuers". Trends in Entreprenuers, 6.

Ernst, N. (1996). Data Arsitek Jilid 2 Edisi 33. Jakarta: Erlangga.

Ergin, D. (2013). How to Create a co-working space handbook. Milan. Politecnico di Milano.

Healt, T. (1984). Method In Architecture. Chicester: John Wiley and Sons.

Hecht, J. (2015, Juni 25 ). Why Millennials are Turning to Entrepreneurship as a Career Choice. Retrieved from mic.com: https://mic.com/articles/121295/why-millennials-are-turningto-entrepreneurship-as-a-career-choice\#.0FboP4FvO

J.G.C. (Jasper) van de Koevering.The preferred characteristics of coworking spaces.2017.Einhoven University of Technology

Kwiatkowski, Angel, dan Buczynski, Beth. Coworking: Building Community as a Space catalyst.2011.

Leforestier, A. The Co-Working Space Concept.CINE Term Project; Indian Institute of Management (IIMAHD): Ahmed, India, 2009

Martens, Y. (2010). Planning Office Spaces: a Practical Guide For Managers and Designer . Laurence King Publishing.

Millennials at work - Reshaping the workplace. (2011). 28.

Neufert, E. (1996). Data Arsitek Jilid 1 Edisi 33. Jakarta: Erlangga. 
Nuring, A. (2018, April 18). Bagaimana Generasi Millenial Merubah Trend.https://Koinworks.com/generasi-millenial-generasi-terkaya/

Page semi-protected. (n.d.). Retrieved from wikipedia.org: https://en.wikipedia.org/wiki/Millennials

Peta Online. (n.d.). Retrieved from peta.bpn.go.id: http://peta.bpn.go.id/ Raskin, E. (1974). Architecture And people. New Jersey: Prentice Hall.

Rouse, M. (2018, August 19 ).Deffinition Millenial Generation.Retrieved from: https//whatis.techtarger.com/deffinition/millenials-millenial-generation

Snyder, J. C., dan Catanese, J. C. (1985). Pengantar Arsitektur. Jakarta: Erlangga.

Whitepaper, R. W. (n.d.). Attracting and Retaining Millennial Professionals. 20. 
